\title{
O POCHODZENIU POMORSKICH GROBOWCÓW BEZKOMOROWYCH KULTURY PUCHARÓW LEJKOWATYCH
}

\author{
ON THE ORIGIN OF THE POMERANIA LONG BARROWS OF THE FUNNEL \\ BEAKER CULTURE
}

\section{Dobrochna Jankowska}

Instytut Prahistorii, Uniwersytet im. Adama Mickiewicza ul. Św. Marcin 78, 61-809 Poznań, Poland

\begin{abstract}
The article presents a short overview of discussion on the origin of the Funnel Beaker Culture in particular regions of Pomerania. In particular, an origin of the Pomerania long barrows with a stone construction is debated. The study implies that prototypes of these monuments are to be found in the Lower Elbe region and influences from Kujavia are only detectable in the latest phase. The article tackles also a theory linking an emergence of long barrows with the late Danubian tradition (,long houses").
\end{abstract}

Grobowce bezkomorowe są specyficzną formą megalitu, charakterystyczną szczególnie dla grupy wschodniej KPL. Zbudowane są z głazów narzutowych, tworzących prostokątną, trapezowatą lub trójkątną obstawę - ramę otaczającą nasyp ziemny lub kamienno-ziemny. Konstrukcja obstawy, obecność lub brak dodatkowych konstrukcji pod nasypem, sposób pozyskiwania ziemi i metoda usypania kurhanu, a także forma i liczba grobów oraz zastosowany ryt pogrzebowy stanowią cechy różnicujące poszczególne grobowce. Różnią się one także rozmiarami. Najwięcej obiektów bardzo dużych, o długości przekraczającej $100 \mathrm{~m}$, w świetle obecnego stanu badań należy do grupy posiadającej obstawę w kształcie wydłużonego trójkąta. Drugie w kolejności co do rozmiarów są grobowce $\mathrm{z}$ obstawą prostokątną. Wśród form trapezowatych znajdują się zarówno konstrukcje niewielkie, o długości 13-20 m, jak i większe, dochodzące do $60 \mathrm{~m}$.

$\mathrm{W}$ archeologii europejskiej pojęcie grobowca bezkomorowego rozszerza się niekiedy na inne obiekty z długimi nasypami, posiadające czasem obstawę drewnianą, niemegalityczną ramę kamienną lub obie te konstrukcje ${ }^{1}$.

Grobowce bezkomorowe wszystkich typów rejestrowane są na obszarze zachodniej, północnej i środkowej Europy oraz na Wyspach Brytyjskich. Występują w różnym nasyceniu, grupując się szczególnie na terenach Dolnej Saksonii, w środkowej i północnej

\footnotetext{
${ }^{1}$ Midgley 1985.
} 
Jutlandii oraz na ziemiach polskich. Najbardziej rozpowszechnioną terytorialnie formą są obiekty trapezowate. Formy prostokątne występują głównie na zachód od Odry, a trójkątne charakterystyczne są niemal wyłącznie dla obszaru Kujaw i przyległych partii Wielkopolski, gdzie określa się je mianem grobowców kujawskich. W polskiej literaturze przedmiotu, szczególnie starszej, nazwę tę rozciaga się na wszystkie neolityczne kamienne grobowce bezkomorowe. Moim zdaniem, powinna być ona używana wyłącznie dla obiektów z obstawą trójkątną, gdyż wyróżniają się one zdecydowanie spośród innych.

W zasięgu grupy wschodniej KPL znajduje się, poza Kujawami, kilka innych regionów, w których zarejestrowano grobowce bezkomorowe z obstawą megalityczną. Występują one na Dolnym Śląsku², na ziemi chełmińskiej oraz na Pomorzu. Bardzo intensywne procesy dewastacyjne, które szczególnie XIX w. spowodowały zniszczenie większości tych obiektów, utrudniają oszacowanie pierwotnej ich liczby oraz ustalenie, czy stwierdzona wyspowość występowania grobowców odpowiada ich rzeczywistemu rozprzestrzenieniu. Niedawne odkrycia nowych cmentarzysk w Strzelinie (Dolny Śląsk) i Mostowie na Pomorzu ${ }^{3}$ dowodzą niezbicie, że nie mamy w tej mierze pełnego rozeznania. Wiadomo jednak, że najliczniej w skali europejskiej występowały one na Pomorzu (ponad 300 obiektów) oraz na Kujawach, gdzie jeszcze w XIX w. było ich przynajmniej 260 (ostatnio K. Gorczyca ${ }^{4}$ dotarł do nieznanej wcześniej notatki E. Raczyńskiego o skupisku ponad 150 grobowców z okolic Kleczewa). W porównaniu z liczba około 110 obiektów bezkomorowych KPL znanych łącznie z innych regionów Europy ${ }^{5}$ jest to liczba rzeczywiście imponująca, uprawniająca do uznania megalitycznego grobowca bezkomorowego za jeden z podstawowych wyznaczników grupy wschodniej KPL.

Na terenie Pomorza grobowce bezkomorowe występują w rejonie Dolnej Odry i Zalewu Szczecińskiego oraz na terenach otaczających Zastoisko Pyrzyckie ${ }^{6}$. Drugie wyraźne skupisko tych obiektów znajduje się w dorzeczu środkowej Łupawy ${ }^{7}$. Mniejsze, kilkuobiektowe koncentracje lub pojedyncze obiekty występują w okolicach Koszalina i Sławna ${ }^{8}$.

Geneza KPL na Pomorzu nie została kompleksowo rozpoznana, choć w ostatnich latach notujemy w tej dziedzinie znaczne postępy. Problemem pozostaje szczególnie odtworzenie dziejów tej kultury na Pomorzu Zachodnim, gdzie podejrzewamy istnienie oddzielnego, dolnoodrzańskiego ośrodka inicjalnego ${ }^{9}$, w którego tworzeniu i rozwoju stylistycznym miały udział protonelityczne ugrupowania nadbrzeżne oraz impulsy pochodzenia wielkopolskiego i dolnołabskiego. Podobnie zapewne kształtowała się grupa łupawska, dla której ciągle nie można wykluczyć istnienia ośrodka inicjalnego w okolicach

\footnotetext{
${ }^{2}$ Wojciechowski 2005.

${ }^{3} \mathrm{I} 1 \mathrm{kiewicz} 2001$.

${ }^{4} \mathrm{G}$ orczyca 2005.

${ }^{5} \mathrm{Midgley} 1985$, s. 30 .

${ }^{6} \mathrm{Chmielewski}$ 1952; Sprockhoff 1967.

${ }^{7} \mathrm{~W}$ ierzbicki 1998.

${ }^{8}$ Gorczyca 1976 ; Ilkiewicz 2001

${ }^{9}$ Jankowska 1990; Galiński 2005.
} 
Dąbek koło Darłowa. W wypadku grupy lupawskiej udało się ustalić, że pierwsze impulsy kulturowe typu pucharowego pochodzą znad Dolnej Łaby ${ }^{10}$ i są znacznie silniejsze niż cechy podobnego pochodzenia, które udaje się rozpoznać na Pomorzu Zachodnim. Natomiast wpływy z właściwej grupy wschodniej, pochodzenia kujawskiego lub chełmińskiego, są nieco późniejsze i nie mają ciagłego charakteru (bardzo słaba frekwencja elementów typu lubońskiego ${ }^{11}$ ). Pomorze Wschodnie było niezbyt intensywnie penetrowane przez ugrupowania kujawskie i chełmińskie, głównie w fazie wióreckiej. W świetle najnowszych badań ${ }^{12}$ zarysowuje się tu niewielkie, nie do końca jeszcze rozpoznane skupisko osadnicze w dolinie Wierzycy.

W świetle powyższych ustaleń szczególnego znaczenia nabiera kwestia pochodzenia występujących na Pomorzu grobowców bezkomorowych, to znaczy wskazania, czy są one na tym terenie częścią ,pakietu” kulturowych cech dolnołabskich czy kujawskich. Na marginesie tych rozważań konieczne będzie także odniesienie się do generalnych koncepcji dotyczących genezy tych obiektów. Problem ten spróbujemy naświetlić, poszukując kolejno analogii formalnych dla obiektów pomorskich, a następnie analizując detale obrządku pogrzebowego, elementy wyposażenia grobów oraz ich chronologię.

Pomorskie grobowce bezkomorowe występują w skupieniach (tworząc cmentarzyska) oraz pojedynczo. Wielkość cmentarzysk jest trudna do oszacowania, ale źródła XIX-wieczne wspominają o skupiskach liczących ponad 20 obiektów ${ }^{13}$. Największe zachowane do dziś cmentarzysko na stan. 2 w Łupawie liczy 11 obiektów megalitycznych. Wszystkie zbadane cmentarzyska są wielofazowe. Na niektórych (bardzo rzadko) spotyka się też atypowe formy komorowe. Wydaje się natomiast, że regułą było występowanie na tych cmentarzyskach niemegalitycznych grobów płaskich.

Nekropolie zlokalizowane są poza osadami, ale w dość bliskim ich sąsiedztwie (w odległości nie przekraczającej $2 \mathrm{~km}^{14}$. Przy lokalizacji cmentarzysk nie starano się szczególnie o wybór eksponowanego terenu. Nie zawsze też próbowano wzmocnić monumentalność obiektu, lokując go na naturalnym wyniesieniu terenowym. O ile grobowce z Pomorza Zachodniego mają raczej jednolitą orientację i występują w układach uporządkowanych, o tyle na cmentarzyskach grupy łupawskiej orientacja obiektów jest zróżnicowana, a grobowce budowane są z reguły w niewielkich odległościach od siebie. Przestrzeń między nimi jest często wykorzystywana przez obiekty towarzyszące współczesne lub młodsze (w tym groby płaskie).

Wszystkie dotąd zbadane wykopaliskowo pomorskie grobowce bezkomorowe charakteryzują się następującymi cechami:

- kształt obstawy jest niemal zawsze trapezowaty, bardzo rzadko - prostokątny. Informacje archiwalne o grobowcach trójkątnych z Pomorza Zachodniego nie znajdują

\footnotetext{
${ }^{10} \mathrm{~W}$ ierzbicki 1999, s. 244

"J Jakkowska 1980, s. 151; Wierzbicki 1999, s. 244252.

${ }^{12}$ Felczak 1984; 1998.

${ }^{13} \mathrm{Chmielewski} 1952$.

${ }^{14}$ Wierzbicki 1992, s. 73.
} 
potwierdzenia ${ }^{15}$; obiekty grupy hupawskiej mają często charakterystycznie łukowato uformowaną ścianę czołową;

- mimo dostępności budulca o dużych gabarytach do konstruowania obstawy wybierano głazy rzadko przekraczające $1 \mathrm{~m}$ wysokości; kamienie wkopywano blisko siebie, co eliminowało konieczność dodatkowego uszczelniania ściany, starając się zachować opadającą ku wierzchołkowi obiektu linię górnej krawędzi obstawy;

- przestrzeń wewnątrz obstawy była poprzecznie dzielona na sektory; zdarzały się także inne przejawy organizacji przestrzeni obiektu za pomocą układów kamieni o wielkości porównywalnej z głazami obstawy lub niewiele mniejszych; na zewnątrz, w części czołowej grobowców o większych rozmiarach występowala ława kamienna;

- nasyp budowany był $z$ dwóch warstw: dolnej - kamiennej, ułożonej z kilku poziomów bruku ze średniej wielkości otoczaków, oraz górnej - ziemnej; prawdopodobnie calkowita wysokość nasypu nie była zbyt imponująca ${ }^{16}$;

- dla grobowców pomorskich charakterystyczny jest birytualizm; formy grobów są zróżnicowane, od jam szalowanych drewnem, przez jamy z obstawą i brukiem kamiennym do pochówków warstwowych;

- wyposażenie grobów może być bogate (kilka naczyń, paciorki bursztynowe, „skarb" krzemienny) lub zupełnie symboliczne (orzech laskowy w grobie dziecka w grobowcu 1 na stan. 2 w Lupawie).

- w obrębie obstawy lub pod nią mogą występować nie związane z pochówkami depozyty ceramiki.

Chronologia pomorskich grobowców bezkomorowych w świetle obecnego stanu badań obejmuje okres między 3250 a 2700 p.n.e. (konv.). W grupie łupawskiej występują dwa okresy, jak się wydaje, zwiększonej intensywności ich budowy: w fazie $Ł$ II ( 3150 -3050 p.n.e.) i w fazie $\lfloor\text { IVa (2850-2700 p.n.e. })^{17}$. Badane wykopaliskowo cmentarzyska z Pomorza Zachodniego odpowiadają czasowo raczej tej drugiej fazie ${ }^{18}$.

Obiekty bezkomorowe z Pomorza mogły pełnić zarówno swą podstawową funkcję, jak i - w wypadku obiektów występujących pojedynczo - służyć jako punkty graniczne, wyznaczające zasięg terytorium eksploatowanego przez grupę, a nawet jako drogowskazy na szlakach komunikacyjnych ${ }^{19}$. Ponieważ żaden $z$ samotnie stojących obiektów tego typu nie został zbadany, trudno stwierdzić, czy były one także grobowcami.

Lokalizacja pomorskich grobowców bezkomorowych, wyłączając grupę łupawską, w zasadzie odpowiada sytuacji obserwowanej na innych obszarach. Warto odnotować, że na zachód od Odry obiekty te znacznie częściej występują pojedynczo bądź w dużym rozproszeniu. Duże cmentarzyska złożone wyłącznie z takich konstrukcji znane są jedynie z ziem polskich. O ile przy tym na Kujawach zdarza się wykorzystywanie pod

\footnotetext{
${ }^{15} \mathrm{~W}$ ierzbicki 1992, s. 77.

${ }^{16}$ Tamże, s. 79

${ }^{17}$ Wierzbicki 1999, s. 246.

${ }^{18} \mathrm{~W}$ iślański 1984, s. 22; Chłodn icki 1997, s. 215.

${ }^{19}$ Wierzbicki 1998 , s. 58.
} 
nekropolię terenu wcześniej zamieszkanego (np. Sarnowo ${ }^{20}$ ), o tyle cmentarzyska pomorskie zakładane były na surowym korzeniu lub, być może, na nie uprawianym już polu (Lupawa, stan. 15) ${ }^{21}$.

Kształty obstaw obiektów pomorskich oraz ich wymiary zbliżone są bardziej do tego, co obserwujemy na obszarach zaodrzańskich i na Dolnym Śląsku. Są to przede wszystkim formy trapezowate średnich rozmiarów. Nie udało się potwierdzić obecności na Pomorzu grobowców o obstawach trójkątnych, charakterystycznych dla grobowców kujawskich. W odniesieniu do grupy łupawskiej J. Wierzbicki ${ }^{22}$ dość stanowczo stwierdza, że dane archiwalne o występowaniu w jej zasięgu obiektów typu kujawskiego są niewiarygodne. Niektóre obstawy obiektów pomorskich wykazujajednak pewne podobieństwa do wzorców kujawskich. Dotyczy to największych budowli, które czasem mają jedną dłuższą ścianę charakterystycznie zaklęśniętą (Łupawa, stan. 18, szczególnie grobowiec $1)^{23}$. Na tym jednak podobieństwo w zasadzie się kończy. Znacznie więcej zbieżności formalnych można znaleźć $\mathrm{z}$ obiektami znad Dolnej Łaby czy Jutlandii. Widać je na przykład w sposobie konstrukcji nasypu i w zwyczaju dzielenia wnętrza grobowca na części. Pierwowzorów obstaw prostokątnych także chyba należy szukać na zachodzie, gdzie ta forma jest bardziej popularna. Birytualizm również zdecydowanie częściej potwierdzony jest na zachodzie ${ }^{24}$.

W obiektach pomorskich, poza incydentalnym przypadkiem domniemanego wystapienia drewnianego szalunku w jamie grobowej grobowca 1 na stan. 18 w Lupawie nie zaobserwowano występowania konstrukcji drewnianych, stosunkowo częstych na Kujawach. Wyposażenie grobów jest na Pomorzu w porównaniu z Kujawami relatywnie bogatsze. W grobowcach kujawskich nie zaobserwowano dotąd pochówków ciałopalnych.

Zróżnicowanie funkcjonalne grobowców bezkomorowych może być zjawiskiem powszechnym. J. Hodder ${ }^{25}$, opierając się głównie na źródłach zachodnioeuropejskich, stwierdza, że grupują się one przeważnie na peryferiach ekumeny wstęgowej. J. Ho$i k a^{26}$ próbowal, co prawda wykorzystując wszelkiego typu megality, wyznaczać przy ich użyciu granice neolitycznych stref trwale odlesionych. Ostatnio K. Gorczyca ${ }^{27}$, analizując lokalizację obiektów tzw. kleczewskiego skupiska grobowców kujawskich, zauważył, że pojedyncze obiekty występują tam na granicy strefy czarnoziemnej i uznał, że są one „kamieniami granicznymi” wyznaczającymi zasięg użytkowanej rolniczo strefy intensywnego osadnictwa KPL. J. Wierzbicki ${ }^{28}$ bardzo przekonująco wykazał istnienie ograniczonego megalitami tzw. łupawskiego mikroregionu osadniczego.

\footnotetext{
${ }^{20} \mathrm{Kruk}, \mathrm{M}$ ilis a uskas 1999, s. 106.

${ }^{21} \mathrm{~J}$ ank ow ska 1975 , s. 37.

${ }^{22} \mathrm{~W}$ ierzbicki 1999 , s. 75.

${ }^{23}$ W e ber 1983 , tabl. XIV.

${ }^{24} \mathrm{~W}$ i erzbicki 1992 , s. $83-87$.

${ }^{25} \mathrm{H}$ odder 1999, s. 31 .

${ }^{26} \mathrm{Ho} \mathrm{ik} \mathrm{a} 1990$.

${ }^{27}$ Gorczyca 2005.

${ }^{28}$ Wierzbicki 1998.
} 
Materiał ceramiczny występujący w grobowcach z Pomorza zawiera zawsze pewne cechy wywodzące się z szeroko pojętej grupy północnej KPL, nawiązujące szczególnie do stylistyki nadłabskiej. Bardzo wyraźnie cechy te są widoczne w grupie łupawskiej. Równocześnie w obiektach tych, wylączywszy kilka najlepiej zachowanych naczyń (Ł.15, gr. 4 ; Ł.18, gr. 1; Ł. 2, gr. 5), które wyglądają na importy, brakuje ceramiki o cechach jednoznacznie ,niżowych”.

Chronologia grobowców kujawskich w świetle najnowszych szacunków zamyka się w obrębie wczesnych faz KPL (faza I?-IIIa(IIIb?) wg A. Kośko), to znaczy między około 3500-2800 p.n.e.. Najstarszy grobowiec grupy łupawskiej (nr 2 ze stan. 15 w Łupawie) J. Wierzbicki ${ }^{29}$ skłonny jest datować już na schyłek fazy ŁIb, czyli na około 3150 p.n.e. Jego zdaniem dopiero od fazy następnej (ŁII) w regionie łupawskim dają się zauważyć pierwsze, słabe świadectwa kontaktów z obszarem Kujaw lub ziemi chełmińskiej. Grobowce wykazujące omawiane wyżej podobieństwa do grobowców kujawskich zaliczane są przez J. Wierzbickiego do fazy ŁIVa (2850 2600 p.n.e. $)^{30}$, a więc, jeśli te szacunki są prawidłowe, powstawały wtedy, gdy w regionie kujawskim w zasadzie przestano już takie budowle wznosić. Datowanie grobowców bezkomorowych w Europie Zachodniej jest bardzo nieprecyzyjne, nie tylko ze względu na słaby stan ich zachowania, ale i ze względu na znaczne rozbieżności w klasyfikacji tychże. Zgodnie $\mathrm{z}$ ustaleniami M. Midgley ${ }^{31}$, obiekty z Jutlandii nie były budowane przed 3200 p.n.e. (daty wyraźniej powiązane z tymi obiektami oscylują między 3060 (Lindebjerg) a 2900 p.n.e. (Konens Hoj), natomiast obiekty z obszaru Dolnej Łaby mogły, według J. Wierzbickiego, powstać już około 3250 p.n.e. Autor ten ${ }^{32}$ przekonujaco wykazuje, że korzenie grupy łupawskiej znajdują się w rejonie Dolnej Łaby, a bardziej precyzyjnie - w rejonie Lauenburg-Stormarn w południowym Holsztynie. Znajduje się tam skupisko grobowców bezkomorowych (Sachsenwald), a forma niektórych z nich, szczegóły konstrukcyjne oraz birytualny obrządek pogrzebowy i cechy stylistyczne ceramiki świadczą wyraźnie, że tu należy szukać wzorców kulturowych dla najwcześniejszych faz grupy lupawskiej. Tym samym można uznać za udokumentowaną tezę, iż idea budowy pomorskich grobowców bezkomorowych jest pochodzenia zachodniego i dopiero kilkaset lat później została lekko zmodyfikowana pod wpływem impulsów płynących ze strefy wielkodolinnej. Ludność grupy łupawskiej stosowała przy budowie swych grobowców także szereg własnych, oryginalnych rozwiązań, gdzie indziej nie spotykanych.

Powyższe ustalenia wyjaśniają, skąd i w jakiej kolejności idea obiektów bezkomorowych docierała na Pomorze. Można jeszcze rozważyć, skąd generalnie wywodzi się idea budowy takich obiektów. Mimo że można odnieść wrażenie, iż hipoteza łącząca grobowce bezkomorowe z długimi domami ludności późnowstęgowej zyskała powszechną akceptację, a próby wyjaśnienia transformacji ideowej domu w grobowiec są coraz bardziej

\footnotetext{
${ }^{29}$ Wierzbicki 1999, s. 246.

${ }^{30}$ Tamże.

${ }^{31} \mathrm{Midgley} \mathrm{1985, \text {s. } 2 2 2 .}$

${ }^{32}$ Wierzbicki 1998, s. 53.
} 
wnikliwe i szczegółowe ${ }^{33}$, ciągle pozostają wątpliwości, nie pozwalające na zamknięcie dyskusji na ten temat. Mimo że historyczne już zapytania K. Jażdżewskiego ${ }^{34} \mathrm{w}$ tej kwestii, wskazujące na wyraźną w każdym aspekcie, poza samym kształtem, kontrastowość obu tych budowli, są przez niektórych współczesnych autorów lekceważone, nie można, moim zdaniem, całkowicie ich ignorować. Nie wdając się w przytaczanie bardzo już rozbudowanych wywodów różnych autorytetów, chciałabym zwrócić uwagę tylko na kilka szczególów.

Ustalenia J. Hoddera ${ }^{35}$ wskazywałyby, że długie grobowce bezkomorowe pojawily się niezależnie w dwóch regionach Europy: w enklawie kujawskiej oraz w Nadrenii, skąd rozprzestrzeniły się na północ i zachód, wyznaczając w Europie Zachodniej pośrednio zasięg tamtejszego osadnictwa późno- i epiwstęgowego. Miało to mieć związek z odmiennym stylem osadnictwa społeczności uczestniczących w procesie transformacji systemowej. $W$ osadnictwie tym, o charakterze rozproszonym, dom i osiedle przestawały pełnić funkcję ogniska wspólnotowego. Miało to zaowocować, w drodze dość skomplikowanych procesów myślowych, odebraniem znaczenia domowi dla żywych i przeniesieniem go na dom dla zmarlych, do którego odchodzi się, wracając w ten sposób do wspólnoty.

J. Hodder ${ }^{36}$, cytując A. Sherratta, dopatruje się bardzo licznych podobieństw formalnych między trapezowatymi grobowcami bezkomorowymi a długimi domami wstęgowców. Zagadnienie to rozpatruje globalnie, nie przejmując się specjalnie faktem, że największe podobieństwo występuje między domami kultury brzesko-kujawskiej a grobowcami z obstawą trapezowatą, które w regionie kujawskim akurat są bardzo nieliczne. Natomiast z kultury rösseńskiej znane są obok chat trapezowatych także budowle prostokątne, nawiązujące kształtem i sposobem budowy do chat KCWR lub zupełnie specyficzne budowle „łodziowe”. Może to znaczyć, że budowniczowie grobowców nie byli wiernymi naśladowcami. Także hipoteza o jednoczącym grupę „domu dla zmarłych" znacznie lepiej pasuje do grobowców komorowych, które, jako mogiły zbiorowe, używane przez pokolenia. niewątpliwie egzystowały w świadomości grup jako wyraźny punkt odniesienia. Tymczasem obiekty bezkomorowe nie były w zasadzie przeznaczone do wielokrotnego użytku, a niekiedy w ogóle nie były budowane w celach cmentarnych.

Zastanawia także inna kwestia. Zgodnie z inną teorią J. Hoddera ${ }^{37}$ jedną z najważniejszych przyczyn transformacji społeczności zbieracko-łowieckich w ugrupowania rolnicze były przyczyny natury ideologicznej. Sposób postrzegania świata i związany z tym zespół czynności rytualno-magicznych praktykowanych przez silne ekonomicznie grupy późnowstęgowe miał być atrakcyjny dla ludności zbieracko-łowieckiej. Ponieważ ówcześnie obowiązujący rytuał regulował wszelkie czynności i zachowania ludzkie i stanowił z nimi nierozerwalną całość, przyjęcie nowego światopoglądu musiało się dokonać

\footnotetext{
${ }^{33}$ Sherratt 1990; Czerniak 1994; Hodder 1990.

${ }^{34} \mathrm{~J}$ ażdże wski 1970 , s. 29.

${ }^{35}$ Hodder 1999, s. 31.

${ }^{36}$ Tamże.

${ }^{37}$ Hodder 1984
} 
łącznie $z$ przyjęciem nowych rozwiązań gospodarczych. Teza ta wydaje się bardzo przekonująca i chyba najlepiej tłumaczy zachodzące na Niżu procesy neolityzacyjne, co nie znaczy, że w procesach tych nie odegrały roli także inne czynniki ekonomiczne czy społeczne. Hipoteza ta ma jednak sens wtedy, gdy przyjmiemy, że cały ten ,pakiet ideologiczno-gospodarczy" był przyjmowany w całości, gdyż, jak słusznie zauważa S. Ku$\mathrm{kawka}^{38}$, odejście od rytuału, czy nie dość dokładne jego przestrzeganie mogło w świadomości ówczesnych ludzi być kojarzone z niepowodzeniami w sferze gospodarczej i wszelkimi innymi nieszczęściami. Jak więc wytłumaczyć fakt, że społeczności KPL, a także inne europejskie ugrupowania pucharowe wykazują w sferze kultury duchowej daleko idące odmienności w stosunku do modelu wstęgowego, widoczne szczególnie właśnie w obrządku pogrzebowym ${ }^{39}$ ? Od samego początku swego istnienia nie są naśladowcami, lecz stosują własne rozwiązania technologiczne i odmienną symbolikę. W kulturach pucharowych nie spotyka się na przykład idoli kobiecych. W materiale archeologicznym wczesnych faz KPL nie dostrzegamy śladów okresu, w którym ten nowy system zostaje przejęty i zweryfikowany jako nieskuteczny.

W świetle powyższego, niezwykle istotna staje się kwestia odkrywanych ostatnio coraz powszechniej (lub reinterpretowanych) grobowców palisadowych KPL. Szczególnie ważne wydaje się potwierdzenie ich występowania w czarnoziemnej strefie Kujaw ${ }^{4 n}$, wyjątkowo nasyconej osadnictwem wczesnopucharowym ${ }^{4 !}$. Analogie między długimi domami wstęgowymi a grobowcami z obstawą drewnianą są zdecydowanie bliższe. Podążając za hodderowskim tokiem myślenia, budowanie przez rozpraszającą się grupę drewnianego domu dla zmarłych można tłumaczyć jako próbę sprostania przez nią, w niesprzyjających już realiach, obowiązującym wymogom formalnym i rytualno-magicznym. Dalszym etapem tego postępowania mogła być decyzja o budowie obiektów kamiennych jako bardziej trwałych, a ich monumentalny charakter mógł być rekompensatą za niedotrzymanie reguły. Niestety, nie wiadomo na razie dokładnie, jakie są relacje chronologiczne między obiektami drewnianymi i kamiennymi.

Kamienny grobowiec przestał więc być normalnym domem dla zmarłego, a stał się metaforą domu, a wkrótce zyskal dodatkowe znaczenie symboliczne, nie tyle jednoczące, ile zamykające grupę na jej terytorium ${ }^{42}$. Izolacja ta nie była jednak zbyt szczelna, o czym może świadczyć zarówno nagminne wykraczanie osadnictwa KPL poza ową hipotetyczną linię graniczną, jak i sporadyczna obecność w obrębie strefy „zamkniętej” stanowisk przypisywanych współczesnym KPL innym kulturom neolitycznym, a także płynące $z$ tych kultur silne i najwyraźniej chętnie przejmowane oddziaływania, widoczne choćby w stylistyce ceramiki.

\footnotetext{
${ }^{38} \mathrm{Kukawk}$ a 1997 , s. $30-31$

${ }^{39} \mathrm{Cofta}-\mathrm{B}$ roniewska, Kośk o 2002, s. 37.

${ }^{40}$ Kośko 1976; Czerniak 1994, s. 132.

${ }^{41}$ Czerniak 1994, s. 130.

${ }^{42}$ Wierzbicki 1998, s. 57; 1999, s. 205.
} 


\section{BIBLIOGRAFIA}

\section{Chłodnicki M.}

1997 Megalithic Graves in Western Pomerania, (w:) The Built Environment of Coast Areas during the Stone Age. The Baltic Sea-Coast Landscapes Seminar, Session No. 1. red. D. Król, Gdańsk, s. $214-216$.

Chmielewski W.

1952 Zagadnienie grobowców kujawskich w świetle ostatnich badań [Résume]. Poznań.

Cofta-Broniewska A., Kośko A.

2002 Kujawy w pradziejach i starożytności, Inowrocław - Poznań.

Czerniak L.

1994 Wczesny i środkowy okres neolitu na Kujawach. 5400-3650 p.n.e. [Sum.: Early and Middle Period of the Neolithic in Kuiavia], Poznan.

Felczak O.

1984 Zagadnienie neolityzacji Pomorza Gdańskiego w aspekcie nowych odkryć archeologicznych między Wierzycq a Wista, (w:) IX Sesja Pomorzoznawcza, Gdansk, 22-23 III 1984, Materiały, red. A. Szymańska, Gdańsk, s. 10-19.

1998 Najstarsze osadnictwo neolityczne w rejonie Jeziora Rokickiego [Sum.: Early Neolithic Settlement in the Region of Lake Rokickie], „Pomorania Antiqua” t. XVII, s. 9-30.

\section{Galiński T.}

2005 Nowe materiaty tzw. fazy wczesnopucharowej osadnictwa protoneolitycznego na Pomorzu, „Folia Praehistorica Posnaniensia" t. XIII, s. 71-90.

Gorczyca K.

1976 Obrzqdek pogrzebowy ludności kultury pucharów lejkowatych na Pomorzu. Poznań (maszynopis pracy magisterskiej w bibliotece Instytutu Prahistorii UAM w Poznaniu).

2005 Kleczewska enklawa grobowców kujawskich. Zarys problemu. „Folia Praehistorica Posnaniensia" t. XIII, s. 117-132.

Hoika J.

1990 Megalithic Graves in the Funnel Beaker Culture of Schleswig-Holstein, „Przegląd Archeologiczny" t. 37, s. 53-119.

Hodder I.

1984 Burials, Houses, Women and Men in the European Neolithic, (w:) Ideology, Power and Prehistory, eds. D. Müller, C. Tilley, Cambridge.

1990 The Domestication of Europe, Oxford.

1999 Megaliths - production and reproduction, (w:) Studien zur Megalithik. Forschungsstand und ethnoarchäologische Perspektiven, ed. K.W. Beinhauer u.a., Weissbach, s. 29-36.

Il kiewicz J.

2001 Nieznane groby megalityczne w dolinie Radwi (Mostowo, gm. Manowo, stanowiska l i 2), „Koszalińskie Zeszyty Muzealne" t. 23, s. 147-153.

Jankowska D.

1975 Cmentarzysko kultury pucharów lejkowatych w Lupawie, pow. Stupsk (stanowisko 15), „Sprawozdania Archeologiczne" XXVII, s. 27-42.

1980 Kultura pucharów lejkowatych na Pomorzu. Grupa lupawska [Zus.: Die Trichterbecherkultur in Mittelpommern], Poznań.

1990 Spoteczności strefy poludniowo-zachodniobaltyckiej w dobie neolityzacji [Zus.: Gemeinschaften des südwestlichen Ostseeraums in der Neolithisierungszeit], Poznań.

Jażdżewski K.

1970 Zwiqzki grobowców kujawskich w Polsce z grobami megalitycznymi w Niemczech pólnocnych, w Danii i w krajach zachodnioeuropejskich [Zus.: Die Verbindungen der kujawischen Gräber in Polen mit der Megalithgräbern in Norddeutschland, in Dänemark und in der westeuropäischen 
Ländern], , Prace i Materiały Muzeum Archeologicznego i Etnograficznego w Lodzi”, seria archeologiczna 17 , s. 15-48.

Kośko A.

1976 Przyczynek do badań nad geneza i rozwojem kujawskiej enklawy tzw. ..grobowców bezkomorowych", "Archeologia Polski” t. 21, z. 2, s. 402-408.

Kruk J., Milisauskas S.

1999 Rozwój i upadek spoteczenstw rolniczych neolitu [Sum.: The Rise and fall of Neolithic Societies], Kraków.

Kukawka S.

1997 Na rubiezy środkowoeuropejskiego świata wczesnorolniczego [Sum.: On the Boundary of the Early Agrarian World. The Communities of Chelmno-Land from IV thousand years BC], Torun.

Midgley M.

1985 The Origin and Function of the Earthen Long Barrows of Northen Europe, Oxford, BAR, IS 259.

Sherratt A.

1990 The genesis of megaliths monumentality, ethnicity and social complexity in Neolithic north-west Europe, „World Archaeology” 22, s. 147-167.

Sprockhoff E.

1967 Atlas der Megalithgräber Deutschlands, t. 2, Mecklenburg - Brandenburg - Pommern, Bonn.

Weber A.

1983 Studia nad obrzqdkiem pogrzebowym grupy lupawskiej kultury pucharów lejkowatych, Poznań. Wierzbicki J.

1992 Cmentarzysko kultury pucharów lejkowatych w Eupawie woj. Stupsk, stanowisko 2 [Zusammenfassung], Poznań.

1998 Dynamiczny model tupawskiego mikroregionu osadniczego (ŁMO) ludności kultury pucharów lejkowatych [Zus.: Das dynamische Model Łupawer Siedlungsregion von Bevölkerung der Trichterbecherkultur], ,Acta Archaeologica Pomoranica” I, Szczecin, s. 53-68.

1999 Lupawski mikroregion osadniczy ludności kultury pucharów lejkowatych [Zus.: Łupawa-Siedlungsmikroregion der Bevölkerung der Trichterbecherkultur], Poznań.

Wiślański T.

1984 Bezkomorowe grobowce neolityczne na Ziemi Pyrzyckiej, (w:) LX Sesja Pomorzoznawcza, Gdańsk 22-23 III 1984 r. Materialy, red. A. Szymańska, Gdańsk, s. 20-24.

Wojciechowski W.

2005 Grobowce megalityczne na przedpolu Sudetów, „Folia Praehistorica Posnaniensia” t. XIII, s. $161-173$.

\section{ZUR HERLEITUNG DER POMMERSCHEN KAMMERLOSEN GROSSSTEINGRÄBER DER TRICHTERBECHERKULTUR}

\section{Zusammenfassung}

Die kammerlosen Großsteingräber sind eine spezielle Megalithform, welche besonders für die Ostgruppe der Trichterbecherkultur (TBK) typisch ist. Sie sind aus großen Steinblöcken errichtet, welche eine rechteckige, trapezoide oder dreieckige Einfassung einer Erd- oder einer Stein-Erde-Aufschüttung bilden. Ausmaße, Konstruktion der Einfassung, Ab- oder Anwesenheit zusätzlicher Konstruktionen unter der Aufschüttung, die Art der Erdgewinnung, die Methode der Aufschüttung, wie auch Form und Anzahl der Gräber sowie der gewählte Bestattungsritus sind Merkmale, welche die einzelnen Grabbauten unterscheiden. Die meisten sehr großen Anlagen mit $100 \mathrm{~m}$ überschreitender Länge gehören, nach dem gegenwärtigen Forschungsstand, zu der Gruppe von Gräbern, welche langdreieckige Einfassungen aufweisen. Unter den trapezoiden befinden sich 
sowohl kleine Grabbauten mit Längen von 13 bis $20 \mathrm{~m}$, als auch größere, die $60 \mathrm{~m}$ erreichen. In der europäischen Archäologie werden gelegentlich auch andere Anlagen mit langen Aufschüttungen, die manchmal eine Holzeinfassung, eine nichtmegalithische Steineinrahmung oder beides zusammen besitzen. als kammerlose Grabbauten bezeichnet

Die kammerlosen Großsteingräber aller Typen sind in West-, Nord- und Mitteleuropa sowie auf den britischen Inseln nachgewiesen. Sie konzentrieren sich besonders in Niedersachsen, in Mittel- und Nordjütland sowie in Polen. Geographisch am weitesten verbreitet sind trapezoide Anlagen. Rechteckige treten hauptsächlich westlich der Oder auf, die dreieckigen sind nahezu ausschließlich für Kujawien und den angrenzenden Teil Großpolens charakteristisch, weshalb sie als kujawische Großsteingräber bezeichnet werden (Meiner Ansicht nach sollte der Begriff ausschließlich für die dreieckige Form reserviert bleiben).

Im Bereich der Ostgruppe der TBK sind außerhalb Kujawiens kammerlose Großsteingräber in Niederschlesien, im Kulmer Land sowie in Pommern belegt. Sehr intensive Devastierungsprozesse führten zur Zerstörung der Mehrheit dieser Anlagen und erschweren Schätzungen ihrer ursprünglichen Anzahl. Deshalb ist auch nicht sicher, ob das locker gestreute Auftreten der Großsteingräber ihrer tatsächlichen Verbreitung entspricht. Neue Entdeckungen beweisen, daß wir in dieser Hinsicht keinen völligen Überblick haben. Jedoch ist bekannt, daß sie im europäischen Rahmen am häufigsten in Pommern vertreten waren (noch im 19. Jh. gab es über 300) sowie in Kujawien (wenigstens 260). Das berechtigt zur Anerkennung der kammerlosen Großsteingräber als grundlegendes Kennzeichen der Ostgruppe der TBK.

In Pommern konzentrieren sich diese Gräber im Gebiet der unteren Oder und am Oderhaff, im Pyritzer Gebiet und im Flußgebiet der Lupawa. Kleinere, wenige Anlagen zählende Konzentrationen oder einzelne Gräber treten in der Umgebung von Koszalin und Sławno auf. Alle bislang untersuchten Anlagen zeichnen sich durch folgende Merkmale aus:

Die Form der Einfassung ist nahezu trapezoid, sehr selten rechteckig. Die Anlagen der Łupawa-Gruppe besitzen hâufig eine charakteristische bogenförmige Stirnseite

- Trotz der Erreichbarkeit von größeren Steinblöcken wählte man zur Einfassungskonstruktion selten Steine von mehr als einem Meter Höhe aus. Die Steine wurden dicht beieinander in die Erde gesetzt, was keine zusätzliche Wandabdichtung verlangte und man bemühte sich darum, eine zum Gipfel verlaufende Linie des oberen Einfassungsrandes zu erhalten.

- Die Innenfläche war in Sektoren quergeteilt. Es kommen auch andere Fälle der Einteilung mit Hilfe von Setzungen von Steinen vor, deren Größen denen aus der Einfassung vergleichbar sind oder nur unwesentlich geringer. Außerhalb, im Bereich der Stirnseite von größeren Anlagen, treten Steinbänke auf.

Die Aufschüttung besteht aus zwei Schichten, einer unteren aus halb so großen Steinen, wie die Einfassungsblöcke, die in mehreren Schichten als Pflaster gelegt wurden, und einer oberen aus Erde. Wahrscheinlich war die Gesamthöhe der Aufschüttung nicht allzu imponierend.

- Für die pommerschen Großsteingräber ist Biritualismus typisch. Die Grabformen sind differenziert, von holzverschalten Gruben über Gruben mit Steineinfassung und -pflastern bis hin zu Schichtenbestattungen.

- Die Beigabenausstattung kann reich sein oder völlig symbolisch.

In der Umgebung der Einfassung oder unter ihr können nicht mit Bestattungen in Verbindung stehende Keramik deponierungen auftreten.

Die pommerschen Großsteingräber werden nach dem gegenwärtigen Forschungsstand zwischen 3250 und 2700 v.u.Z. (konv.) datiert. In der Łupawa-Gruppe treten zwei Phasen größerer Bauintensivität auf: Phase LII (3150-3050 v.u.Z.) und Phase ŁIVa (2850-2700 v.u.Z.). Die untersuchten Nekropolen in Westpommern sollte man eher mit der zweiten Phase synchronisieren.

Die kammerlosen Anlagen in Pommern könnten sowohl ihre eigentliche Funktion erfüllt haben, wie auch - im Falle einzeln auftretender Objekte - die von Grenzpunkten, welche den Einzugsbereich eine Population markierten, oder sogar die von Wegweisern auf Kommunikationsrouten. Da jedoch keines der einzeln liegenden Objekte untersucht wurde, ist schwer zu sagen, ob sie auch Gräber waren. Die Form der Einfassungen pommerscher Anlagen sowie auch ihre Ausmaße ähneln eher dem, was wir jenseits der Oder und in Niederschlesien beobachten können. Es gibt in Pommern keine Nachweise von Megalithgräbern mit dreieckigen Einfassungen, wie sie für die Objekte in Kujawien typisch sind. Jedoch zeigen einige pommersche Anlagen Ähnlichkeiten zu 
den Mustern in Kujawien (sie haben eine in charakteristischer Weise abgesenkte Längswand). Weitaus mehr formale Bezüge kann man zu den Objekten an der Niederelbe und in Jütland herstellen. Sie sind beispielsweise in der Art der Aufschüttung und in der Sitte der Gliederung des Inneren in mehrere Teile zu sehen. Die Vorlagen für die rechteckigen Einfassungen sind wohl auch im Westen zu suchen, wo diese Form sehr häufig ist, genauso ist der Biritualismus dort weitaus geläufiger.

Das in den Gräbern Pommerns auftretende Keramikmaterial besitzt bestimmte Merkmale, die mit der breit verstandenen nördlichen Gruppe der Trichterbecherkultur und besonders mit dem Stil an der Elbe zu verbinden sind. Sehr deutlich sind sie in der Łupawa-Gruppe. Gleichzeitig fehlt in diesen Anlagen, die einige am besten erhaltene und nach Importen aussehende Gefäße bargen, Keramik mit „Tieflands”-Merkmalen.

Die Anlagen aus Kujawien datieren nach den neuesten Schätzungen in die frühe Phase der Trichterbecherkultur (ca. 3500-2800 v.u.Z.). Das älteste Megalithgrab der Lupawa-Gruppe (Nr. 2 von Lupawa, Fpl. 15) datiert J. Wierzbicki schon um ca. 3 I 50 v.u.Z., d.h., vor das Auftreten von kulturellen Impulsen aus der Tieflandzone. Die Łupawa-Anlagen, welche Ähnlichkeiten zu den kujawischen Gräbern aufweisen, werden um ca. 2850-2600 v.u.Z. datiert, als im Gebiet von Kujawien im Prinzip schon derartige Anlagen nicht mehr errichtet wurden. Die Datierung kammerloser Megalithgräber in Westeuropa ist wenig präzise. Die Anlagen im Gebiet der Niederelbe könnten nach J. Wierzbicki um 3250 v.u.Z. entstanden sein. Er zeigt überzeugend auf, daß die Wurzeln der Łupawa-Gruppe sich in diesem Gebiet befinden. genauer in der Region Lauenburg-Stormarn im südlichen Holstein. Genauso kann man der These von der westlichen Herkunft der Idee kammerloser Gräber und der erst viele Jahrhunderte später stattfmdenen Übernahme bei leichter Modifizierung unter Einfluß aus der Tieflandszone beistimmen.

Man bekommt den Eindruck, daß die Hypothese von der Verbindung kammerloser Megalithgräber mit Langhäusern allgemein auf Akzeptanz stößt. Nach J. Hodder erschienen diese Gräber unabhängig voneinander in zwei Regionen Europas, in der Enklave in Kujawien und am Rhein, von dort breiteten sie sich nach Norden und Westen aus und markieren in Europa direkt das spät- und epibandkeramische Besiedlungsgebiet. Das soll mit der Ausbreitung der Gemeinschaften verbunden sein, welche Anteil am Systemtransformationsprozeß hatten, innerhalb dessen Haus und Siedlung aufhörten, die Funktion als gemeinschaftlichen Sammelpunkt zu erfüllen. Im Ergebnis soll, auf dem Wege recht komplizierter Denkprozesse. dem Haus die Bedeutung für die Lebenden genommen und diese auf das Haus für die Toten übertragen worden sein, zu denen man weggeht und auf diese Art man gleichzeitig zur Gemeinschaft zurückkehrt.

Die Frage der formalen Ähnlichkeiten zwischen trapezoiden Gräbern und den Langhäusern der Bandkeramik betrachtet J. Hodder global und berücksichtigt nicht den Fakt, daß die größte Ähnlichkeit zwischen den Häusern der Brześć-Kujawien-Kultur und den Gräbern mit trapezoiden Einfassungen besteht, die in der Region von Kujawien wiederum sehr selten sind. Dagegen sind von der Rössener Kultur neben trapezoiden Häusern auch rechteckige Bauten bekannt, welche in Form und Bauspezifika den Häusern der Linienbandkeramik nahestehen, sowie die sehr spezifischen ,schiffsförmigen” Hăuser. Das kőnnte bedeuten, daß sich die Erbauer der Megalithgräber nicht getreu an die Vorbilder hielten. Auch paßt die Hypothese einer Gruppe von „,Totenhäusern" bedeutend besser zu den Kammergräbern, welche, als Mehrfachbestattungsplätze über Generationen benutzt, unzweifelhaft im Gruppengedächtnis als deutliche Bezugspunkte existierten. Damit waren die kammerlosen Anlagen im Prinzip nicht zum häufigen Gebrauch bestimmt und manchmal waren auf keinen Fall als Bestattungsplätze errichtet worden.

Übereinstimmend mit einer anderen Theorie von J. Hodder war eine der wichtigsten Ursachen der gesellschaftlichen Transformation von den Fischern/Sammlern zu den Bauern ideologischer Natur. Da das damalige verpflichtende Ritual sämtliche Tätigkeiten und menschliche Verhaltensweisen regulierte und eine mit ihnen untrennbare Einheit bildete, muß die Annahme einer neuen Weltsicht Hand in Hand mit neuen wirtschaftlichen Lösungen gehen. Diese These erklärt wohl am besten den im Tiefland einsetzenden Neolithisierungsprozeß, was aber nicht bedeutet, daß in diesen Prozessen nicht auch andere wirtschaftliche und gesellschaftliche Faktoren eine Rolle spielten. Sie hat jedoch dann Sinn. wenn das gesamte ,ideologisch-wirtschaftliche Paket” in Gänze übernommen wurde, wenn das Abgehen von den Ritualen im Bewußtsein der damaligen Menschen mit irgendwelchen Unglücken verbunden wurde (S. Kukawka). Damit zeigen die Gemeinschaften der Trichterbecherkultur, aber auch die der anderen europäischen Becherkulturen, in der geistigen Sphäre weitgehende 
Wandlungen in Hinsicht auf das bandkeramische Modell, was besonders eben bej den Bestattungsitten sichtbar wird. Von Beginn ihrer Existenz an sind sie keine Nachahmer, sondern kommen zu eigenen Lösungen. Im archäologischen Material der Frühphase der Trichterbecherkultur fassen wir keine Spuren eines Zeitraumes, in welchem das neue System unwirksam adaptiert und verändert worden wäre.

Im Licht des Vorgenannten scheint die Frage der immer häufiger entdeckten bzw. reinterpretierten Palisadengrabbauten der Trichterbecherkultur ungeheuer bedeutsam. Besonders wichtig ist ihr Auftreten im Schwarzerdegebiet Kujawiens, wo die Besiedlung der frühen Trichterbecherkultur außergewöhnlich dicht ist. Die Analogien zwischen den Langhäusern der Bandkeramik und den Grabbauten mit Holzeinfassung sind entschieden enger. Dem Gedankengang Hodders folgend, kann man die Errichtung hölzerner Totenhäuser durch eine sich ausbreitende Gruppe als ein Versuch der Berichtigung der formalen und rituell-magischen Anforderungen in schon ungeeigneten Realitäten erklären. Die nächste Etappe dieses Fortschritts könnte die Entscheidung gewesen sein, Steinobjekte als länger bestehende Anlagen zu errichten und ihr monumentaler Charakter könnte Rekompensierung der nicht einhaltbaren Regeln sein. Leider ist gegenwärtig das chronologische Verhältnis zwischen den hölzernen und den steinernen Objekten unbekannt.

Übersetzt von Jan Schuster 